\title{
Studies on Group B $\beta$-Hemolytic Streptococcus. I. Isolation and Partial Characterization of an Extracellular Toxin
}

\author{
CARL G. HELLERQVIST, ${ }^{(45)}$ JORGE ROJAS, ${ }^{(42)}$ ROBERT S. GREEN ${ }^{(43)}$ SARA SELL, \\ HAKAN SUNDELL, AND MILDRED T. STAHLMAN
}

Departments of Biochemistry and Pediatrics, Vanderbilt University School of Medicine, Nashville, Tennessee, USA

\begin{abstract}
Summary
To initiate an investigation into the biochemistry and mechanism of group B $\boldsymbol{\beta}$-hemolytic Streptococcus virulence, bacterial cultures grown in suspension were centrifuged, and the bacteria and media were subjected to extensive fractionation. Each fraction was assayed for physiologic activity by repeated intravenous infusion into adult unanesthetized sheep. Pulmonary artery pressure, arterial $\mathrm{Po}_{2}$, and rectal temperature were monitored. The media fraction, but not the bacteria, contained a component (molecular weight, 2 $\times 10^{6}$ ) composed of $84 \%$ carbohydrate and $16 \%$ protein with physiological activity. Two mg quantities, when infused, caused the pulmonary artery pressure to increase $100 \%, \mathrm{Po}_{2}$ to decrease by $20 \%$ and chills and fever. The active component could be degraded by hot phenol-water extraction into a pure polysaccharide (molecular weight, 200,000 ). This lower molecular weight polysaccharide retained the identical physiologic properties when infused in the sheep. The degraded component precipitated with group B-specific antiserum.

This study demonstrates that, in the sheep, a pure polysaccharide is the physiologically active part of a high-molecular-weight toxin synthesized by group B $\beta$-hemolytic Streptococcus type III and that this component has a different carbohydrate composition from the group B capsular antigen.
\end{abstract}

\section{Speculation}

The clinical syndrome associated with group $B \boldsymbol{\beta}$-hemolytic Streptococci in early onset disease is caused by the interactions of an extracellular bacterial component and a specific target tissue in the infected infant.

Group B $\beta$-hemolytic Streptococcus has become a major pathogen in newborn nurseries in the United States (19). Two distinct clinical syndromes have been described (1) depending on the age of presentation. The early onset disease, characterized by a shortlived picture and with a mortality rate in some series of over $50 \%$ $(18,34)$, has been compared clinically by many investigators $(13$, $20,25)$ to gram-negative endotoxin shock. Although the clinical and laboratory picture suggests the presence of bacterial products with endotoxin-like properties, such products have so far not been identified.

The presence of extracellular toxins has been described for a number of strains of group A hemolytic Streptococci. They have been associated with the erythema of scarlet fever, a pyrogenic response in rabbits, and the enhancement of gram-negative endotoxin shock in mice, monkeys, and rabbits $(10,21,38)$. Several workers have attempted to characterize potentially pathogenic extracellular products produced by group B $\beta$-hemolytic Streptococci. Todd, in 1934 (33), described the production of an oxygen stable, non-immunogenic hemolysin; McClean, in 1941 (26), demonstrated that these organisms elaborated a hyaluronidase; Brown et al., in 1974 (6), reported the isolation of the protein's cyclic adenosine 3':5'-monophosphate factor; and Milligan et al. in 1977 (27), described the presence of neuroaminidase (sialidase) in concentrated culture filtrates. The role of these products in the pathophysiology of group $\mathrm{B} \beta$-hemolytic streptococcal disease is speculative at this time.

Stahlman, et al. (32), have shown that the infusion of live and heat-killed organisms into adult sheep produces a reaction that resembles that of gram-negative endotoxins when infused into the same animal model $(4,5)$. We now report that extensive fractionation of the bacteria and its extracellular products have led to the isolation of an extracellular toxin that reproduces this response in adult unanesthetized sheep. A more extensive study with regard to the effect of the toxin on the pulmonary vasculature is reported in a second paper.

\section{MATERIALS AND METHODS}

\section{BACTERIAL CULTURES}

The group B $\beta$-hemolytic Streptococci type III strain used in this study was isolated from an infant who died of septicemic shock at Vanderbilt University Hospital.

Cultures were started in $50 \mathrm{ml}$ of Trypticase Soy from a single colony picked from a $24 \mathrm{hr}$ incubation of a stock inoculum on a blood agar plate. Modified Todd Hewitt broth (3) was inoculated with the single colony culture and incubated at $35^{\circ} \mathrm{C}$ for $18 \mathrm{hr}$ to serve as inoculum for the large batches. Flasks containing 1.5 liter modified Todd Hewitt broth were seeded with the inoculum and incubated $24 \mathrm{hr}$ at 35 to $37^{\circ} \mathrm{C}$ in a gyratory shaker. The cultures were centrifuged and the supernatant made $80 \%$ in ethanol and left at $5^{\circ} \mathrm{C}$ for $48 \mathrm{hr}$. The bacterial pellet and the alcohol precipitate were fractionated as outlined in Figure 1.

\section{BACTERIAL CONTROLS}

Thirty $\mathrm{ml}$ of the $50 \mathrm{ml}$ inoculum was centrifuged and the pellet was overlayed with $0.5 \mathrm{ml}$ sterile saline and autoclaved $15 \mathrm{~min}$ $\left(121^{\circ} \mathrm{C}\right)$. The supernatant after centrifugation was used for immunologic classification by capillary precipitation tests $(23,35)$ using commercial group B antisera (BBL, Baltimore, MD) and type specific antisera (Texas Children's Hospital). Eosin methylene blue and blood agar (BBL, Baltimore, MD) plates were streaked with the inoculum and incubated for $24 \mathrm{hr}$ to verify the purity of the culture. Batches showing any abnormality in the inoculum controls were discarded.

Samples from each 1.5 liter flask after the 24-hr incubation were subjected to gram stain and streaked in duplicate onto blood, trypticase soy, and eosin methylene blue agar plates. One set of plates was incubated at $35^{\circ} \mathrm{C}$ for $24 \mathrm{hr}$ and the other at room temperature for $72 \mathrm{hr}$. A flask showing any abnormality in the control plates after $24 \mathrm{hr}$ was discarded, and if contamination was detected in any of the 72-hr control plates, the whole batch was 


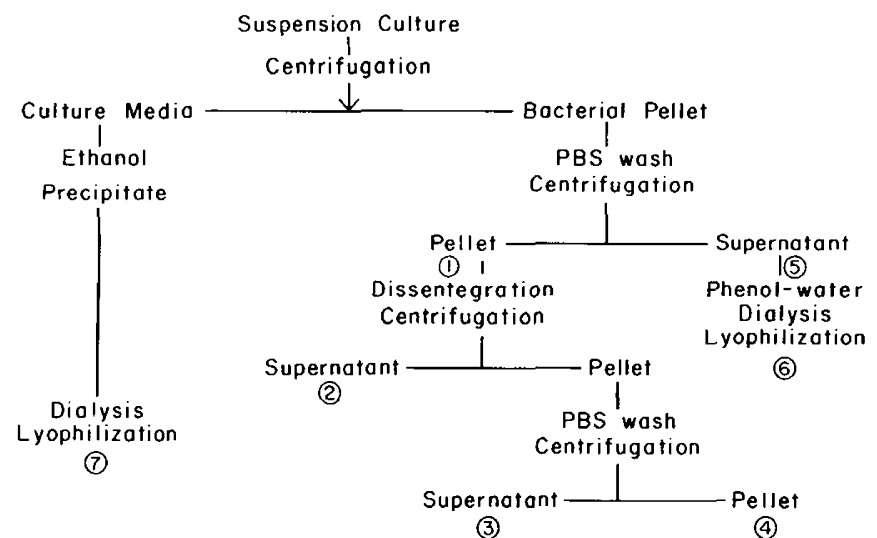

Fig. 1. Fractionation scheme used for the bacterial pellet and media alcohol precipitate.

rejected. This latter plate streaking and incubation procedure was performed on each sample in the various fractions (described later) before and after dialysis to ensure that no bacterial, fungal, or yeast contamination was introduced during the fractionation and purification procedures.

\section{LIMULUS LYSATE ASSAY}

Limulus lysate, Escherichia coli LPS control standard, and methodology was obtained from Associates of Cape Cod, Ind., Woods Hole, MA. Solutions of fraction 7B1 were compared with E. coli and Salmonella typhosa lipopolysaccharides (LPS).

\section{MOUSE LETHALITY STUDIES}

Swiss Webster Albino Mice (approximately $18 \mathrm{~g}$ ) were used. Lead sensitization was performed as described by Rifkind (30). Briefly, $2 \mathrm{mg}$ lead acetate in $100 \lambda$ of $5 \%$ dextrose was injected intravenously followed immediately by an intravenous dose of toxin in $100 \lambda$ of $5 \%$ dextrose. Control groups received the lead acetate or toxin solutions alone. Mice were observed for 2 days.

\section{cGMP ASSAY}

The toxin was compared with S. typhosa endotoxin for its ability to affect cyclic 5'-monophosphate (cGMP) levels in fetal rat liver cell preparation by the method of Graber et al. (14).

\section{BACTERIAL PELLET FRACTIONATION}

The pellet obtained by centrifugation of a 16 liter culture at $100,000 \times g$ for $20 \mathrm{~min}$ was washed with $600 \mathrm{ml}$ phosphatebuffered saline by gentle pipetting. After centrifugation, 1/10th of the pellet (heat-killed bacteria) was used for infusion as Fraction 1 , and the remaining $\%$ iths were disintegrated in a Brown disintegrator (16) (B. Brown, Apparatenbau, Melsungen, Germany) and centrifuged at $20,000 \times \mathrm{g}$ for $10 \mathrm{~min}$. The supernatant from this centrifugation was used as fraction 2 (cell lysate), and the pellet was subjected to a PBS wash and repelleted. The supernatant so obtained was fraction 3 , and the pellet was fraction 4 (cell wall material). The supernatant $(600 \mathrm{ml})$ from the initial centrifugation was divided into two fractions. One fraction was dialyzed, lyophilized, and infused as fraction 5 (capsular material). The second fraction was extracted once with an equal volume of phenol at $80^{\circ} \mathrm{C}$, and the water phase was then dialyzed, lyophilized, and used as fraction 6 (capsular polysaccharides).

\section{MEDIA FRACTIONATION}

Cultures grown for $22 \mathrm{hr}$ were centrifuged without autoclaving, and the supernatant was made $80 \%$ in ethanol. The precipitate, fraction 7, was dissolved in 1 liter of water and dialyzed against distilled water. After lyophilization, the material was subjected to gel filtration on Sephacryl S-200 $(5 \times 80 \mathrm{~cm})$ in $0.2 \mathrm{M} \mathrm{NH}_{4} \mathrm{Cl}, 1$
mM Tris (tris-(hydroxymethyl)-aminomethane-HCl) buffer, $\mathrm{pH}$ 7.2. Portions of $50 \mathrm{ml}$ were loaded onto the column, and the void volumes from several runs were pooled and dialyzed against 2 mM Tris, pH 7.2. This material was then pumped onto a DEAESephacel column $(2.5 \times 20 \mathrm{~cm})$ (Pharmacia, Uppsala, Sweden) equilibrated with $2 \mathrm{mM}$ Tris buffer, $\mathrm{pH}$ 7.2. The column was then washed with $300 \mathrm{ml}$ of starting buffer after which a gradient from 0 to $0.4 \mathrm{M}$ sodium chloride was applied. Fractions were collected off the columns in acid washed tubes and assayed for carbohydrate content by the phenol-sulphuric method. The material not adhering to the column was dialyzed and lyophilized and assayed in the animal model as fraction 7-II. fraction 7-I, the gradient peak, was dialyzed, lyophilized, and subjected to Sepharose 6B chromatography $(2.6 \times 80 \mathrm{~cm})$ (Pharmacia, Uppsala, Sweden) in the ammonium chloride-Tris buffer. Three components were detected by the phenol-sulfuric assay. Fractions 7I-1 through 7I-3 were dialyzed and lyophilized.

\section{PHENOL-WATER EXTRACTION OF FRACTION 7I-1}

Two $\mathrm{mg}$ of fraction 7I-1 were dissolved in $1 \mathrm{ml}$ of water and heated slowly $(30 \mathrm{~min})$ to $70^{\circ} \mathrm{C}$. One $\mathrm{ml}$ phenol at $70^{\circ} \mathrm{C}$ was added and mixed. The solution was allowed to cool slowly (30 min), and the water phase was extracted with hot phenol once more, then dialyzed against $2 \mathrm{mM}$ Tris buffer, $\mathrm{pH} 7.2$, and applied to a DEAE-Sephacel column $(1 \times 6 \mathrm{~cm})$. Eight $\mathrm{ml}$ Tris buffer were passed through the column, after which the column was eluted with $0.2 \mathrm{M}$ sodium chloride. The carbohydrate-containing material, eluted in the gradient, was applied to the Sepharose $6 \mathrm{~B}$ column equilibrated in $0.2 \mathrm{M}$ ammonium chloride, $0.2 \mathrm{mM}$ Tris, pH 8.

\section{PHENOL-WATER EXTRACTION OF MEDIA}

Media alcohol precipitate, fraction 7, from 16 liter cultures was dissolved in 2 liters of water and subjected to two hot phenolwater extractions (39). The water phase was then dialyzed against distilled water. Acetic acid was added to $\mathrm{pH} \mathrm{4,} \mathrm{followed} \mathrm{by} 20 \mathrm{mg}$ of pepsin (Worthington Corp., Freehold, NJ). After a $48 \mathrm{hr}$ incubation at $37^{\circ} \mathrm{C}$, the material was dialyzed and lyophilized and subjected to the fractionation procedure outlined above.

\section{CONTROL FRACTIONS}

Two one-liter batches of medium were incubated at $37^{\circ} \mathrm{C}$ for $22 \mathrm{hr}$ and fractionated as outlined for fraction $7 \mathrm{I}-1$ to serve as control fraction (fraction 9). In addition, $0.9 \%$ sodium chloride (saline) solution was used as control fraction (fraction 8).

\section{CARBOHYDRATE ANALYSIS}

Two hundred $\mu \mathrm{g}$ of material from various fractions were subjected to sugar analysis using accepted methodology $(15,17)$. Briefly, material was dissolved in $3 \mathrm{ml}$ of $90 \%$ acetic acid, and the mixture was kept at $100^{\circ} \mathrm{C}$ for $8 \mathrm{hr}$ to hydrolize $\mathrm{N}$-acetyl-glycosaminidic linkages (17). After removal of acetic acid by evaporation, $0.5 \mathrm{~N} \mathrm{H}_{2} \mathrm{SO}_{4}$ was added, and the sample was heated at $100^{\circ} \mathrm{C}$ for $12 \mathrm{hr}$ for complete hydrolysis. Barium carbonate(s) was added, and the filtered solution of sugars was reduced $2 \mathrm{hr}$ by the addition of $10 \mathrm{mg} \mathrm{NaBD}$. Acetic acid was then added to $\mathrm{pH} \mathrm{3}$, and the mixture was evaporated to dryness. Methanol was then added and evaporated five times to remove the borate, and the alditols were acetylated in pyridine-acetic acid anhydride (1-1) for $1 \mathrm{hr}$. The mixtures of alditol acetates were analyzed quantitatively by gas chromatography on a Sigma 1 gas chromatograph (Perkin-Elmer, Newark, NJ) equipped with an OV-225 open tubular glass column $(10 \mathrm{~m})$. Positive identification of the peaks as sugar derivatives was accomplished on a quadropole mass spectrometer (Finnegan Corp, Sunnyvale, CA) equipped with an OV-225 6-foot packed column (Applied Science Labs, State College, PA). The sample was analyzed for fatty acids by injection on a SP-1000 open tubular glass column (20 m) (Suppelco, Inc., Bellefonte, PA). 
Sialic acid was determined by the method of Warren et al. (37) and by gel filtration of isolated fractions labeled with $\mathrm{N}$-acetyl-D$\left[{ }^{3} \mathrm{H}\right]$ mannosamine (Amersham Searle Corp., Arlington Heights, IL) after partial acid hydrolysis $\left(0.05 \mathrm{M}\right.$ sulphuric acid at $80^{\circ} \mathrm{C}$ for $1 \mathrm{hr}$ ).

\section{AMINO ACID ANALYSIS}

Samples were hydrolized for $20 \mathrm{hr}$ in $6 \mathrm{~N} \mathrm{HCl}$ and analyzed on a Beckman automatic amino acid analyzer (28) for the presence of amino acids, muramic acid, and diaminopamelic acid.

\section{SHEEP MODEL}

Fourteen young Dorset or Suffolk sheep were used for screening of the fractions. Five to 7 days before the infusions, a left thoracotomy was performed under general anesthesia with nitrous oxide and halothane. A large pericardial window was resected, and a catheter was placed directly into the pulmonary artery. At the same time, catheters were placed in the thoracic aorta through the left carotid artery and in the left jugular vein. In all experiments, the unanesthetized sheep were awake and standing unrestrained in a cage with access to food and water. Pulmonary arterial and aortic pressures were monitored continuously with Statham pressure transducers (model P23Gb; Gould-Statham Instruments, Inc., Hato Ray, Puerto Rico) and recorded on a Sanborn 350 six-channel recorder (Sanborn Co., Waltham, MA). At 15-min intervais, rectal temperature was recorded with a YSI telethermometer (Yellow Springs Instrument Co., Yellow Springs, $\mathrm{OH})$ and arterial $\mathrm{Po}_{2}, \mathrm{PCO}_{2}$, and $\mathrm{pH}$ were measured with a $\mathrm{pH}-$ blood gas analyzer model 213 (Instrumentation Laboratory, Inc., Lexington, MA).

All the fractions were infused initially in amounts equivalent to material from $10^{12}$ bacteria diluted in $100 \mathrm{ml}$ of $0.9 \% \mathrm{NaCl}$ solution. After at least $1 \mathrm{hr}$ of baseline observation of vascular pressures, rectal temperature, and arterial blood gases, a fraction was infused into the jugular vein over $30 \mathrm{~min}$, and observation continued for a minimum period of $3 \mathrm{hr}$ or until all values returned to baseline. At least $48 \mathrm{hr}$ were allowed for recovery in between infusions.

\section{RESULTS}

All statistical calculations to compare values before and after infusion were done using a two-tailed paired $t$ test. A $P$ value of less than 0.05 was accepted as significant. Of the parameters measured when the different fractions were infused in the sheep at concentrations corresponding to material obtainable from $10^{12}$ bacteria, changes were seen only in pulmonary artery pressure, arterial $\mathrm{Po}_{2}$, and rectal temperature. Systemic arterial pressure remained stable throughout all the experiments, and arterial $\mathrm{PCO}_{2}$ and $\mathrm{pH}$ did not show significant changes for any fractions.

\section{CONTROL FRACTIONS}

A total of five control infusions were performed. Three were saline, and two were fractionated growth media. The infusion data are shown in Table 1 and demonstrate that there was no change in either of the measured parameters.

\section{BACTERIAL FRACTIONS}

Infusions of fractions 1 through 6 obtained from the bacterial pellets were done in three different sheep, and, as seen in Table 1, no significant changes were observed in any of the parameters.

\section{MEDIA FRACTIONS}

The media fractions obtained by DEAE chromatography, fractions $7 \mathrm{I}$ and 7II, were assayed twice each in the sheep, and the data are summarized in Table 2. Gel filtration of fraction 71 gave three components: fraction 7I-1, marginally included, indicating
Table 1. Physiologic response in sheep to infusion of control and bacterial fractions

\begin{tabular}{lccc}
\hline & $\begin{array}{c}\text { Pulmonary } \\
\text { artery } \\
\text { pressure } \\
(\mathrm{mm} \mathrm{Hg})\end{array}$ & $\begin{array}{c}\text { Arterial } \\
\mathrm{Po}_{2} \\
\text { (torr) }\end{array}$ & $\begin{array}{c}\text { Rectal } \\
\text { temperature } \\
\left({ }^{\circ} \mathrm{C}\right)\end{array}$ \\
\hline $\begin{array}{l}\text { Control fractions } \\
\text { Saline }(8)^{1}(n=3)^{2}\end{array}$ & & & \\
$\quad$ Baseline & $17.8 \pm 0.9^{3}$ & $97.9 \pm 5.5$ & $39.5 \pm 0$ \\
$\quad$ Infusion & $18.6 \pm 2.3$ & $99.8 \pm 7.1$ & $39.6 \pm 0.1$ \\
& & & \\
Media (9) $(n=2)$ & $15.1 \pm 3.8$ & $74.5 \pm 1.5$ & $39.5 \pm 0$ \\
$\quad$ Baseline & $16.2 \pm 2.9$ & $75.8 \pm 4.2$ & $39.6 \pm 0.1$ \\
$\quad$ Infusion & & & \\
& & & \\
Bacterial fractions (1- & & & \\
6) ( $n=10)$ & $17.6 \pm 2.4$ & $92.17 \pm 5.2$ & $39.3 \pm 0.2$ \\
$\quad$ Baseline & $19.2 \pm 1.5$ & $87.17 \pm 5.1$ & $39.8 \pm 0.3$ \\
\hline Infusion &
\end{tabular}

${ }^{1}$ Numbers in parentheses, fraction number.

${ }^{2} n$, number of infusions.

${ }^{3}$ Mean \pm S.E.

Table 2. Physiologic response in sheep to media fractions

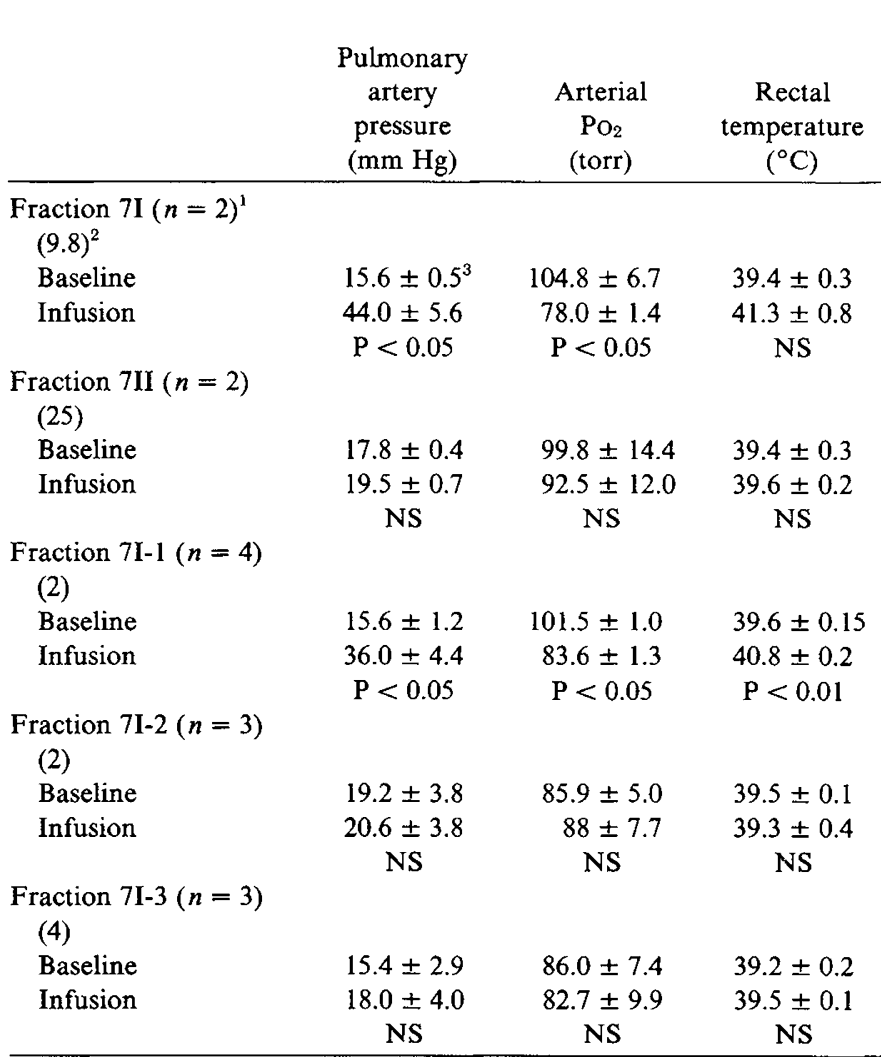

${ }^{1} n$, number of infusions.

${ }^{2}$ Numbers in parentheses, $\mathrm{mg}$ material in $100 \mathrm{ml}$ of saline.

${ }^{3}$ Mean \pm S.E.

a molecular weight of $2 \times 10^{6}$; and fractions 7 I-2 and 7I-3, included on the column.

These fractions, when assayed in the sheep, showed that only fraction 7I-1 had the biological activity seen with fraction 7I, but at an elevated specific activity (Table 2). Fraction 7I-1 did not give a distinct precipitate with either group or type specific antisera in the microprecipitin tests $(23,35)$. 
PHENOL-WATER EXTRACTED MATERIAL

Gel filtration of the carbohydrate-containing material obtained from fraction 7I-1 by phenol-water extraction gave one component on the Sepharose 6B column which eluted as a symmetris peak at $275 \mathrm{ml}$ (column volume, $456 \mathrm{ml}$; void volume by Blue Dextran 180) suggesting a molecular weight of $2 \times 10^{5}$ which was dialyzed and lyophilized (yield, $1 \mathrm{mg}$ ). This material, fraction 7B1, obtained from Fraction 7I-1 tested physiologically active in the sheep (Table 3).

The phenol-water extracted media precipitate yielded one component corresponding to fraction $7 \mathrm{Bl}$ by its elution properties on the various columns, chemical compositions, and physiologic properties. Several infusions of fraction 7B1, obtained from different cultures after phenol-water extraction of the media precipitate, showed identical results with respect to physiological changes (Table 3), and a typical response is shown in Figure 2. No other subfraction showed any significant physiologic activity when tested in the sheep.

\section{DOSE RESPONSE}

Fraction 7B1 pooled from several batches $(290 \mathrm{mg})$ when chromatographed on DEAE-Sephacel in ammonium acetate yielded $270 \mathrm{mg}$ in a symmetric peak with identical sugar composition in the beginning, middle, and tailing end of the peak. This material, 7B1, which now was precipitable with group B antisera, was used to determine the dose response in the sheep. As seen in Figure 3, there is an exponential response which levels off at 62 $\mu \mathrm{g} / \mathrm{kg}$, corresponding to $2 \mathrm{mg}$ infused in an average sheep.

\section{CHEMICAL CHARACTERIZATION OF FRACTION 7B1 AND 7I-1}

The two physiologically active components (fractions 7B1 and 7I-1) were subjected to amino acid analysis. The sensitivity of the instrument allowed detection of $50 \mathrm{ng}$ of muramic, diaminopamilic, and amino acids. Neither fraction contained even trace amounts of muramic acid or diaminopamilic acid and is thus not of cell wall origin. This was as expected because cell wall fractions were physiologically inactive in the sheep. Fraction 7B1 contained no amino acids, which was corroborated by protein analyses (24), whereas fraction $7 \mathrm{I}-1$ contained $16 \%$ amino acids by weight. The amino acid composition of fraction $7 \mathrm{I}-1$ is shown in Table 4 . The two fractions were analyzed for phosphate (9) with negative results.

Carbohydrate analysis of fraction 7B-1, obtained by phenolwater extraction of either media precipitate or purified fraction 7I-1, showed an identical carbohydrate composition of mainly Dmannose and some D-glucose with trace amounts of L-rhamnose and D-galactose (Table 5). Fraction 7I-1 was composed of these

Table 3. Physiologic response in sheep to phenol-water extracted media fractions

\begin{tabular}{llcc}
\hline & $\begin{array}{c}\text { Pulmonary } \\
\text { artery } \\
\text { pressure } \\
(\mathrm{mm} \mathrm{Hg})\end{array}$ & $\begin{array}{c}\text { Arterial } \\
\mathrm{Po}_{2} \\
(\text { torr })\end{array}$ & $\begin{array}{c}\text { Rectal } \\
\text { temperature } \\
\left({ }^{\circ} \mathrm{C}\right)\end{array}$ \\
\hline $\begin{array}{l}\text { Phenol-water extract } \\
\text { of fraction 7I-1 }\end{array}$ & & \\
$(n=1)^{1}(1)^{2}$ & & & \\
Baseline & 14.0 & 105 & 39.1 \\
$\quad$ Infusion & 43.0 & 86 & 40.6 \\
Fraction 7BI $(n=7)$ & & & \\
$\quad$ (1.6) & & & \\
Baseline & $15.3 \pm 1.0^{3}$ & $96 \pm 3$ & $39.3 \pm 0.1$ \\
Infusion & $40.3 \pm 2.0$ & $73 \pm 4$ & $40.2 \pm 0.3$ \\
& $\mathrm{P}<0.01$ & $\mathrm{P}<0.01$ & $\mathrm{P}<0.02$ \\
\hline
\end{tabular}

${ }^{1} n$, number of infusions.

${ }^{2} \mathrm{mg}$ material in $100 \mathrm{ml}$ of saline.

${ }^{3}$ Mean \pm S.E.
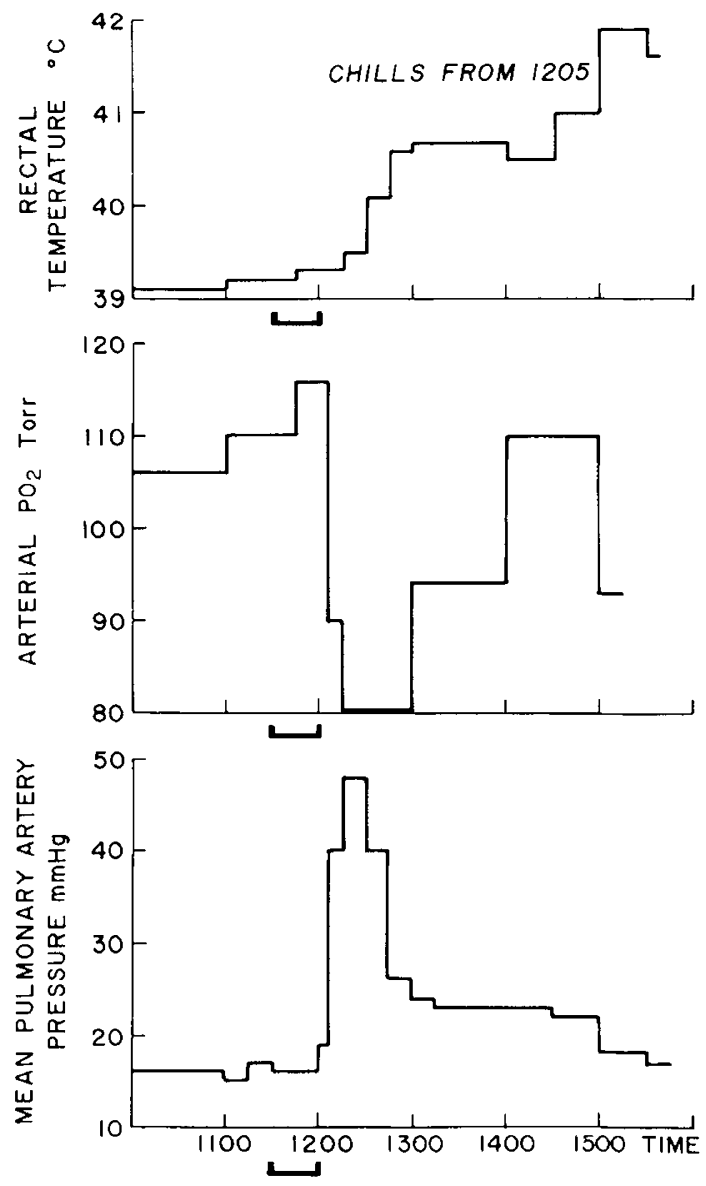

Fig. 2. Typical response in sheep to $2 \mathrm{mg}$ of fraction 7B1. Time of infusion is indicated on the time scale by a bracket.

Dose Response Curve VS-25-80

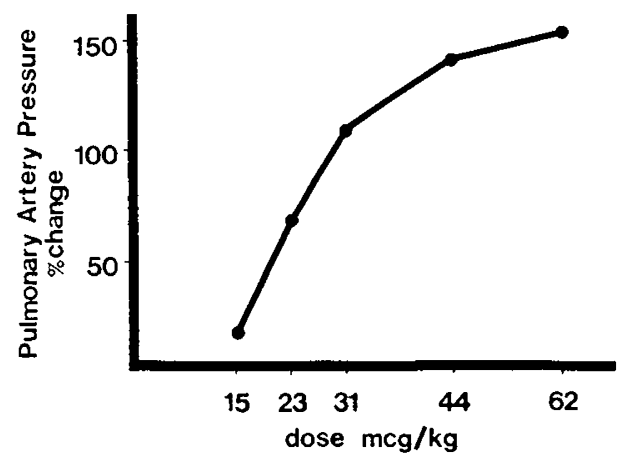

Fig. 3. Pulmonary artery pressure response to different doses of fraction $7 \mathrm{~B} 1$ in one sheep.

sugars and in addition contained 2-acetamido-2-deoxy-D-glucose and 2-acetamido-2-deoxy-D-galactose (Table 5). Fraction 7I-1 contained some partially methylated sugars in minute amounts not found in fraction $7 \mathrm{~B} 1$.

\section{QUANTITATION}

For quantitative purposes and to assure bacterial origin of the two fractions, 1 liter cultures were labeled with $\mathrm{D}-\left[{ }^{3} \mathrm{H}\right]$ glucose or $N$-acetyl-D- $\left[{ }^{3} \mathrm{H}\right]$ mannosamine (New England Nuclear, Boston, MA). Tritiated glucose labeled both active fractions, and in addition, a bacterial mannan was labeled (Fig. 4). The yield of fractions 7I-1 and 7B1 was approximately $7 \mathrm{mg}$ from the 1 liter cultures containing $10^{11}$ bacteria. Thus, $2 \mathrm{mg}$ used in the sheep 
Table 4. Amino acid analysis of $130 \mu \mathrm{g}$ of fraction 7 I-I

\begin{tabular}{llllll}
\hline Amino acid & $(\mu \mathrm{g})$ & Amino acid & $(\mu \mathrm{g})$ & Amino acid \\
\hline Lysine & 0.223 & Serine & 1.908 & Valine \\
Histidine & 0.134 & Glutamic acid & 1.037 & Methionine \\
Ammonia & N.D. ${ }^{1}$ & Proline & 1.367 & Isoleucine \\
Arginine & 0.140 & Glycine & 1.063 & Leucine \\
Aspartic acid & 0.652 & Alanine & 1.000 & Tyrosine \\
Threonine & 2.208 & Half cystine & 5.378 & Phenylalanine & 0.200 \\
& & & & Total & 0.127 \\
\hline
\end{tabular}

${ }^{1}$ N.D., not detected.

Table 5. Alditol acetates from the hydrolysates of fractions $7 B I$ and $7 I-1$ as identified by combined gas chromatography mass spectroscopy

\begin{tabular}{lccc}
\hline \multicolumn{1}{c}{ Alditol acetates } & $\begin{array}{c}\text { Fraction 7I-1 } \\
\text { (\% of total) })^{1}\end{array}$ & $\begin{array}{c}\text { Fraction 7B1 } \\
\text { (\% of total) }\end{array}$ & $\begin{array}{c}\text { Fraction } \\
\text { 7I-1 } \mathrm{pH}^{-\mathrm{H}_{2} \mathrm{O}} \\
\text { extract } \\
\text { (\% of total) }\end{array}$ \\
\hline Rhamnitol & 6.4 & Trace $^{2}$ & Trace \\
Mannitol & 45.7 & 89.2 & 68.3 \\
Galactitol & 24.2 & Trace & Trace \\
Glucitol & 8.0 & 3.6 & 4.5 \\
Glucosaminitol & 11.3 & & \\
Galactosaminitol & 4.2 & & \\
\hline
\end{tabular}

' total, area of all peaks excluding the solvent peak.

${ }^{2}$ Trace, less than $0.1 \%$.

corresponds to $3 \times 10^{10}$ bacteria assuming $100 \%$ yield in the isolation procedure. The bulk of the isotope $\mathrm{N}$-acetyl-D- $\left[{ }^{3} \mathrm{H}\right]$ mannosamine (precursor for $N$-acetyl-neuraminic acid), however, was found in a smaller polysaccharide corresponding to fraction 7B3 (Fig. 5). When the toxins $7 \mathrm{~B} 1$ and $7 \mathrm{I}-1$ and fraction $7 \mathrm{~B} 3$ were subjected to mild hydrolysis and fractionated on a G-10 column, only $7 \mathrm{~B} 3$ gave a radioactive peak corresponding to sialic acid. The two labeled toxins gave only one peak eluted in the void volume. To further assure the absence of sialic acid in fractions 7B1 and $7 \mathrm{I}-1,100 \mu \mathrm{g}$ of each were subjected to sialic acid analysis by the method of Warren (37) with negative results.

\section{CONTROL FOR GRAM-NEGATIVE CONTAMINATION}

The possibility of gram-negative contamination was investigated chemically by injecting the toxin sample on the gas chromatograph to give $3,917,777$ area units of mannose. The sensitivity of the instrument could detect as a significant peak 100 units of heptose or 2-acetamido-2-deoxy-D-glucose, both common to endotoxin core structure. A $1 \%$ endotoxin contamination by a smooth LPS would contain at least $2 \%$ heptose and somewhat more amino sugar $(7,16,17)$, or 783 area units. Because none was detected, then, based on the sensitivity of the instrument, there must be less than $100 \mathrm{ng}$ endotoxin per $1000 \mu \mathrm{g}$ of toxin if the former was present. One hundred ng of $E$. coli endotoxin had no physiologic effect when infused into the sheep, whereas $500 \mathrm{ng}$ had a slight effect, in that the pulmonary artery pressure increased from a mean of 17 to $25 \mathrm{~mm} \mathrm{Hg}$ and $\mathrm{Po}_{2}$ decreased from a mean of 111 to 93. Part of the hydrolyzed sample was also analyzed on an SP1000 column for fatty acids with negative results, that is, less than 100 units (if any) when $3 \times 10^{6}$ units of mannose was injected. In addition to common saturated and unsaturated fatty acids, acetylated $\beta$-hydroxy-myristic acid, kindly provided by Dr. J. Coniglio, was used as a standard. Endotoxin from smooth LPS would contain at least $20 \%$ lipid; thus, less than 100 units of lipid means the toxin contains less than $0.01 \%$ endotoxin, if any.

The limulus lysate assay was used as a tool to rule out gramnegative contamination not detected by our culture controls. Several dilution tests were performed, and the toxin fraction 7B1 showed activity at a $5 \mathrm{ng}$ but not at a $1 \mathrm{ng} / \mathrm{ml}$ dilution. S. typhosa
LPS was active at the latter concentration which was the end point. $E$. coli LPS was active down to $0.25 \mathrm{ng} / \mathrm{ml}$. This would suggest that if fraction 7B1 was not active by itself, it would be contaminated at a level of 5 to $20 \%$, an amount which was ruled out by our chemical data.

In the mouse lethality assay (30), the material also showed activity. The dose lethal to $50 \%$ of the mice for $E$. coli endotoxin was $1.2 \mathrm{ng}$ in $100 \lambda$ when infused immediately after $2 \mathrm{mg}$ lead acetate. For fraction 7B1, the following observations were made. Ten mice were infused with $100 \mu \mathrm{g}$ each, and one died after 3 days. When another group of 10 mice were infused with $400 \mu \mathrm{g}$ each, all died. Thus, in this assay, our level of possible contamination is approximately $0.5 \%$ which we ruled out by biochemical means. Toxin alone in amounts up to $1 \mathrm{mg}$ or lead acetate alone at these levels had no effect.

cGMP levels in rat liver cells are increased by incubation with endotoxin (14). The group B streptococcal toxin showed activity also. In this endotoxin assay, $100 \mathrm{ng}$ toxin had the same effect as $1 \mathrm{ng}$ of $S$. typhosa, and $1 \mathrm{mg}$ had the effect of $4 \mathrm{ng}$ rather than of $10 \mathrm{ng}$ endotoxin.

Thus, fraction 7B1 has $20 \%$ of the activity of S. typhosa endotoxin in the limulus lysate assay and $1 \%$ in the cGMP assay. Furthermore, it has $5 \%$ of the activity of $E$. coli endotoxin in the limulus lysate assay and $0.5 \%$ in the mouse lethality assay. Based on these results and our chemical analysis, we conclude that fraction 7B1 is active by itself in these three biological assays and that it contains less than $0.1 \%$ endotoxin contamination, if any. Furthermore, each isolated fractions 7B1 and 7I-1 had the same chemical composition and qualitative physiologic effect in the sheep, whereas the media controls and all other subtractions were inactive.

\section{DISCUSSION}

We have determined that a complex, toxic, high-molecularweight component can be isolated from the culture media of $\beta$ hemolytic Streptococcus group B, type III. This component contains both protein and carbohydrates, and the toxicity is associated with the carbohydrate portion. Fraction 7I-1 is of higher molecular weight and different carbohydrate composition than either the group B or type III polysaccharides $(2,3)$ even when isolated from the culture media under very similar conditions (8). The former seems to correspond to fraction $7 \mathrm{~B} 3$ by molecular weight and sialic acid content.

Fraction 7B1, which is precipitable with group B antibodies after the final purification, and the toxic portion, obtained from 7I-1 by phenol-water extraction, have identical carbohydrate compositions of mainly D-mannose residues and some D-glucose residues. The trace amounts of $\mathrm{L}$-rhamnose may be part of the molecule or some residual group $B$ antigen responsible for the group $B$ reaction in the microprecipitin test. More likely, due to the molecular weight of fraction $7 \mathrm{I}-1$, the toxin portion, $7 \mathrm{~B} 1$, and the group $B$ antigen share some immunologically active structural feature other than L-rhamnose. This could readily be demonstrated by complete structural analyses of the two polysaccharides as has been done with the cross-reacting endotoxins of the Salmonella typhimurium group B (16) and Pasteurella pseudotuberculosis type II (7). 

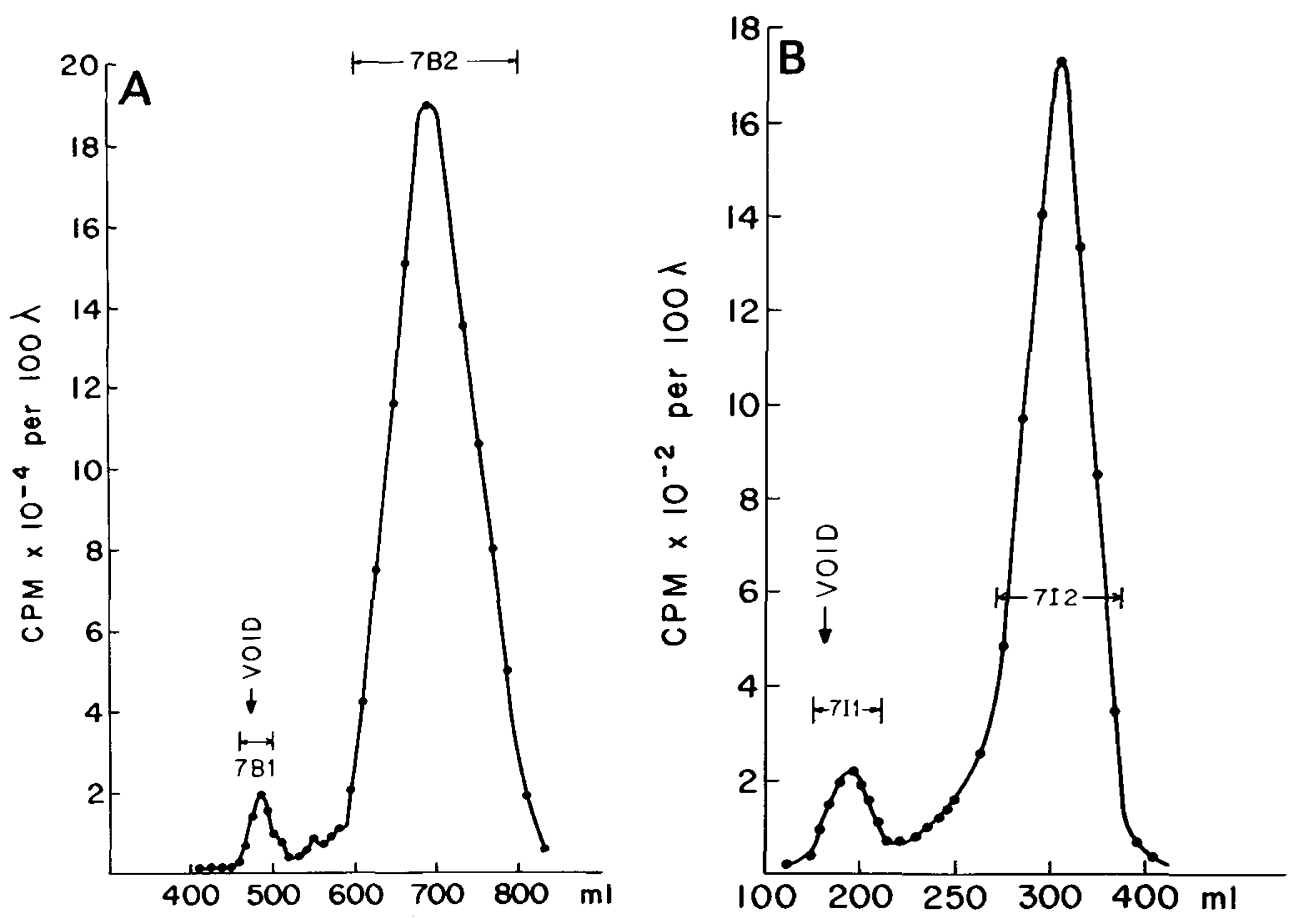

Fig. 4. Elution profile of $\mathrm{D}-\left[{ }^{3} \mathrm{H}\right]$ glucose labeled media fractions. $A$, phenol-water extracted run on $\mathrm{S}-200$. $B$, nonphenol-water extracted run on Sepharose 6B. The second dominant peak in both $A$ and $B$ yields only mannose upon sugar analysis.
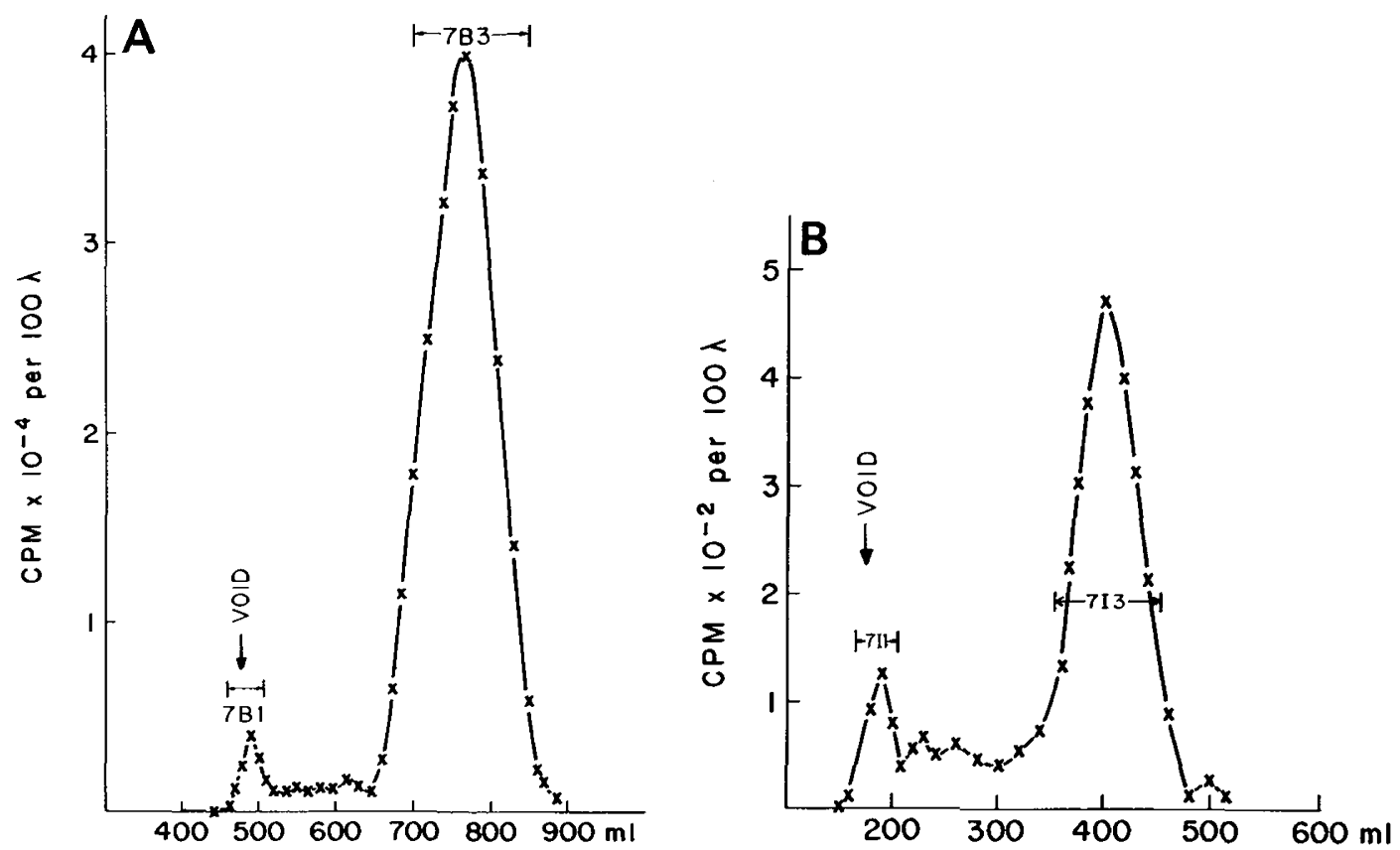

Fig. 5. Elution profile of $N$-acetyl-D- $\left[{ }^{3} H\right]$ mannosamine labeled media fractions. $A$, phenol-water extracted run on S-200. $B$, nonphenol-water extracted run on Sepharose 6B.

The response observed in the sheep with this toxin resembles that of endotoxemia. Gram-negative endotoxemia, however, is generally associated with a lipid component of the lipopolysaccharides, although virulence has been demonstrated to be at least in part associated with the carbohydrate portion (29). Furthermore, antitumor biological activity in vivo by Salmonella endotoxin decreases as carbohydrate is sequentially removed from the polysaccharide end of the LPS (36), suggesting involvement of tumor-associated carbohydrate receptors.

The possibility of endotoxin contamination in spite of extensive microbial controls of both the cultures and the various fractions has been investigated by several endotoxin "specific" assays. The limulus lysate assay showed that $5 \mathrm{ng} / \mathrm{ml}$ of fraction $7 \mathrm{~B} 1$ was active compared to $1 \mathrm{ng}$ of $S$. typhosa. Such a level of endotoxin contamination, as well as the $1 \%$ level suggested by the mouse lethality and cGMP assays would readily be detected chemically. In addition, media controls prepared identically to fraction 7I-1 were inactive, whereas each bacterial preparation yielded one toxic fraction, either 7B1 or 7I-1, based on molecular weight, sugar analysis, and physiologic activity. All other subfractions tested inactive. The probability of only having contaminated each active fraction with equal amounts of the same endotoxin must be 
extremely remote. The Limulus lysate assay is not specific for endotoxin (12), but activity associated with cell wall material from Streptococcus organisms (40) requires a concentration of $100 \mu \mathrm{g} /$ $\mathrm{ml}$, which is 20,000 -fold higher than what is required for the isolated polysaccharide 7B1 to be active. Contamination by cell wall material, which is unlikely because cell wall material showed no physiologic activity, is further ruled out by the absence of even trace amounts of either muramic acid or diaminopamilic acid.

Toxicity of pure polysaccharides is rare and has only been reported once, to our knowledge, in which case a mannan upon IV injection in mice showed high toxicity, which was eliminated by carboxymethylation of the polysaccharide (22). In sheep at least, a polysaccharide is the physiologically active part of group B $\beta$-hemolytic Streptococcus type III and may be relevant to the pathophysiology of the "endotoxin-like" picture seen in "early onset" disease.

The mechanism by which the polysaccharide exhibits the observed virulence is unknown, but occurs presumably through interaction with a target tissue, causing host-mediated physiologic changes analogous to the observed anti-tumor activity demonstrated by polysaccharides in vivo but not in vitro (41). Alveolar macrophages have receptors for mannose residues (31) and because the bacterial polysaccharide toxin is most likely built by repeating units, those receptors would be cross-linked on the membrane and possibly lead to release of lysosomal enzymes which could produce tissue destruction analogous to what is observed with mouse peritoneal macrophages when challenged with infectious agents (11). This and other possibilities are currently under investigation.

\section{REFERENCES AND NOTES}

1. Baker, C. J., Barnett, F., Gordon, R. C., and Yone, H. D.: Suppurative meningitis due to Streptococci of Lancefield group B: A study of 33 infants. J. Pediatr., 82: 724 (1973).

2. Baker, C. J., and Kasper, D. L.: Microcapsule of type III strains of group B Streptococcus: production and morphology. Infect. Immun., 12: 189 (1976)

3. Baker, C. J., Kasper, D. L., and Davis, C. E.: Immunchemical characterization of the native type III polysaccharide of group B Streptococcus. J. Exp. Med., 143: 258 (1976).

4. Brigham, K. L., Bowers, R. E., and Haynes, J.: Increased sheep lung vascular permeability caused by Escherichia coli endotoxin. Circ. Res., 45: 292 (1979).

5. Brigham, K. L., Woolverton, W. C., Blake, T. H., and Staub, N. C.: Increased sheep lung vascular permeability caused by Pseudomonas bacteremia. J. Clin. Invest., 54: 792 (1974).

6. Brown, J., Farnsworth, R., Wannamaker, T. W., and Johnson, D. W.: CAMP factor of group B Streptococci: production, assay, and neutralization by sera from immunized rabbits and experimentally infested cows. Infect. Immun., 9: 377 (1974).

7. Brubaker, R. F., Hellerqvist, C. G., Lindberg, B., and Samuelsson, K.: Studies on lipopolysaccharides from Yersinia pseudotuberculosis. In: S. Winblad: Contributions to Microbiology and Immunology. Vol. 2, pp. 6-9 (S. Karger, Basel, Switzerland, 1973).

8. Carey, R. B., Einstein, T. K., Shockman, E. D., Greber, T. F., and Swenson, R. M.: Soluble group- and type-specific antigens from type III group B Streptococcus, Infect. Immun., 28: 195 (1980).

9. Chen, P. S., Jr., Toribana, T. X., and Warner, H.: Microdetermination of phosphorus. Anal. Chem., 28: 1976 (1956).

10. Cunningham, C. M., Barsumian, E. L., and Watson, D. W.: Further purification of group A Streptococcal pyrogenic exotoxin and characterization of the purified toxin. Infect. Immun., 14: 767 (1976).

11. Dean, R. T., Hylton, W., and Allison, A. C. Induction of macrophage lysosomal enzyme secretion by agents acting at the plasma membrane. Exp. Cell. Biol., 47: 454 (1979).

12. Elin, R. J., and Wolff, S. M.: Nonspecificity of the limulus amebocyte lysate assay, J. Infect. Dis., 128: 349 (1973).

13. Fenton, L. J., and Strunck, R. C.: Complement activation and group B Streptococcal infection in the newborn. Similarities to endotoxin shock. Pediatrics, 60 : 901 (1971).

14. Graber, S. E., Bomboy, J. D., Jr., Salmon, W. D., Jr., and Krantz, S. B.: Evidence that endotoxin is the cyclic $3^{\prime}: 5^{\prime}$-GMP-promoting factor in erythropoietin preparations. J. Lab. Clin. Med., 93: 25 (1973).

15. Hellerqvist, C. G.: Citation Classic: Current Content in Agriculture, Biology, and
Enviromental Sciences. 10: 51 (1979)

16. Hellerqvist, C. G., Lindberg, B., Svenson, S., Holme, T. and Lindbert, A. A. Structural studies on the O-specific side-chains of the cell-wall lipopolysaccharide from Salmonella typhimurium. Carbohydr. Res., 8: 43 (1968).

17. Hellerqvist, C. G., Ruden, U., and Makela, P. M.: The group $C_{2}$ type modification of the B-type lipopolysaccharide in a hybrid between Salmonella groups B and $C_{2}$. Eur. J. Biochem., 25: 96 (1972).

18. Horn, K. A., Meyer, W. T., Wyrick, B. C. and Zimmerman, R. A.: Group B Streptococcal neonatal infection, J. Am. Med. Assoc., 230: 1165 (1974).

19. Howard, G. B., and McCraken, G. H., Jr.: The spectrum of group B Streptococcal infection in infancy. Am. J. Dis. Child., 128: 815 (1974).

20. Jeffery H., Michison, R. Wigleworth, J. A., and Davis, P. A.: Neonatal bacteremia. Arch. Dis. Child., 52: 683 (1977).

21. Kim, Y. B., and Watson, D. W.: A purified group A Streptococcal pyrogenic exotoxin. Physico-chemical and biological properties including the enhancement of susceptibility to endotoxin lethal shock. J. Exp. Med., 131: 611 (1970).

22. Kumano, N.: Antitumor polysaccharides, specially a mannan preparation derived from Candida utilis. Sci. Rept. Res. Inst. Tohoku Univ. Ser. C., 19: 89 (1972); Chem. Abstr., 78: 79, 497 (1973).

23. Lancefield, R. C.: A micro-precipitin-technic for classifying hemolytic Streptococci and improved methods for producing antisera. Proc. Soc. Exp. Biol. Med., 38: 473 (1938).

24. Lowry, O. H., Rosebrough, N. J., Farr, A. A., and Randall, R. L.: Protein measurements with the Folin phenol reagent. J. Biol. Chem., 193: 265 (1951).

25. Maher, E., and Irwin, R. C.: Group B streptococcal infection in infancy: a case report and review. Pediatrics, 38: 659 (1966).

26. McClean, D.: The capsulation of Streptococci and its relation to diffusion factor (hyaluronidase). J. Pathol. Bacteriol., 53: 13 (1941).

27. Milligan, R. W., Straus, D. C., and Mattingly, S. J.: Extracellular neuraminidase production by group B Streptococci. Infect. Immun., 18: 189 (1977).

28. Moore, S., Spackman, D. H., and Stein, W. H.: Chromatography of amino acids on sulphonated polystyrene resins. Anal. Chem., 30: 1185 (1958).

29. Nurminen, M., Hellerqvist, C. G., Valtonen, V. V., and Makela, P. H.: The smooth lipopolysaccharide character of $1,4,(5), 12$ and $1,9,12$ transductants formed as hybrids between groups B and D of Salmonella. Eur. J. Biochem., 22: 500 (1971)

30. Rifkind, D.: Prevention of polymixin B of endotoxin lethality in mice. J. Bacteriol., 93: 1463 (1967).

31. Stahl, P. D., Rodman, J. S., Miller, M. J., and Schesinger, P. H.: Evidence for receptor-mediated binding of glycoproteins, glycoconjugates, and lysosomal glycosidases by alevolar macrophages. Proc. Natl. Acad. Sci. U. S. A., 75: 1399 (1978).

32. Stahlman, M. T., Olegard, R., and Brigham, K. L.: Effects of group B Streptococci on lung fluid balance in unanesthetized sheep. Pediatr. Res., 11: 506 (1977).

33. Todd, E. W.: A comparative serological study of streptolysins derived from human and from animal infections with notes on Pneumococcal hemolysin, titanolysin, and Staphlyococcus toxin. J. Pathol. Bacteriol., 39: 299 (1934).

34. Tseng, P., and Kendall, S. R.: Group B Streptococcal diseases in neonates and infants. N. Y. State J. Med., 74: 2169 (1974).

35. van Slogteren, D. H. M.: Serological micro-reactions with plant viruses under paraffin oil. Proceedings of the 2nd Conference on Potato Diseases. pp. 51-54 (Lisse-Wageningen, 1955).

36. Wasilauskas, B. L., and Cameron, J. A.: Tumor hemorrhagic properties of surface components of Salmonella typhimurium mutants. Cancer (Phila.), 27: 217 (1971).

37. Warren, L.: The thiobarbituric assay of sialic acids. J. Biol. Chem., 234: 1971 (1959).

38. Watson, D. W.: Host parasite factors in group A streptococcal infection. Pyrogenic and other effects of immunologic distinct exotoxins related to scarlet fever toxins. J. Exp. Med., 111: 255 (1960).

39. Westphal, O., and Jann, K.: Extraction with phenol-water and further application of the procedure. Methods Carbohyd. Chem., 5: 83 (1965).

40. Wildfeuer, A., Heymer, B., Schleiter, K. H., and Haferkamp, D.: Investigations on the specificity of the limulus test for the detection of endotoxin. Appl. Microbiol., 28: 867 (1974).

41. Zahl, P. A.: Action of bacterial toxins on tumors VIII. Factors in their use for cancer therapy. J. Natl. Cancer Inst., 11: 279 (1950).

42. Fellow supported by the Tennessee Lung Association

43. Post-Doctoral Trainee supported by USPHS grant HL 07256.

44. The authors are indebted to Zell McGee, M.D., for valuable advice, to Dr. Anne Melley for conducting the limulus lysate and mouse lethality tests, and to Dr. Stanley Graber for performing the cGMP assay. The skilled technical assistance of Gerda Resch, Oscar Towler, David Oliver, Rao Gaddipatti, and Patricia Minton is gratefully acknowledged.

45. Requests for reprints should be addressed to: Dr. Carl G. Hellerqvist, Department of Biochemistry, Vanderbilt University School of Medicine, Nashville, TN 37232 (USA).

46. This research was supported by a grant from the National Institutes of Health HL 22520.

47. Received for publication August 20, 1979.

48. Accepted for publication August 20, 1980. 